Proceedings

\title{
Use of DNA Barcoding to Confirm Invasive Banana Skipper Erionota torus (Evans) from Malabar Region of Kerala
}

\author{
Jaleel K. Abdul 1,* and S. M. Ghosh ${ }^{2}$ \\ 1 Department of Zoology, Government College, Vidhyanagar, Kasaragod, 671123, Kerala. \\ jaleelkabdul@gmail.com \\ 2 Department of Molecular Biology, Kannur University, Nileswar, Kasaragod 671314. smghosh03@gmail.com \\ * Correspondence: jaleelkabdull@gmail.com; Tel.: +91-9995417121 \\ + Presented at the 1st International Electronic Conference on Entomology (IECE 2021), 1-15 July 2021; \\ Available online: $\underline{\text { https://iece.sciforum.net/. }}$
}

Citation: Abdul, J.K.; Ghosh, S.M. Use of DNA Barcoding to Confirm Invasive Banana Skipper Erionota torus (Evans) from Malabar Region of Kerala, in Proceedings of the 1st International Electronic Conference on Entomology, 1-15 July 2021, MDPI: Basel, Switzerland, doi:10.3390/IECE-10601

Published: 5 July 2021

Publisher's Note: MDPI stays neutral with regard to jurisdictional claims in published maps and institutional affiliations.

Copyright: ๑ 2021 by the authors. Submitted for possible open access publication under the terms and conditions of the Creative Commons Attribution (CC BY) license (http://creativecommons.org/licenses/by/4.0/).

\begin{abstract}
Invasion of banana leaf roller Erionota spp. has been noticed in banana plantations of Malabar region of Kerala a part of Western Ghat, India. Researchers currently proposed that banana leaf roller E. thrax and E. torus occur together in Kerala and many have treated them as a single species. Currently there is no published information regarding whether, one or both the species of Erionota coexist during the seasonal outbreak of banana skipper. Since the early stages of $E$. thrax and E. torus cannot be distinguished easily, and as they are common pests of banana, morphological identification of species is difficult. Species level identification is essential in the implementation of effective biological control programmes to manage this pest. This study is aimed to use DNA barcoding to confirm the invasive Erionota species from Malabar region of Kerala. The COI sequences of the banana skipper confirms the existence of E. torus species in the infested areas and all the parasitoid species collected during the course of study where that of E.torus.The life cycle and invasiveness and seasonal fluctuations were also studied. Adult lay small creamy yellow eggs on the under surface of banana leaves. After hatching the various larval instars cause severe damage to leaves by feeding and rolling. This prevents traditional use of leaves, lowers banana yields, fruit maturity and the bunch size. The invasiveness was more during monsoon and post monsoon seasons, ranging from 10 to $40 \%$ and up to $50 \%$ loss of plant leaf area.
\end{abstract}

Keywords:Invasion; Erionota torus; Erionotathrax; DNA barcoding; COI; Musa spp.

\section{Introduction}

Invasive species are those that have established and spread in a new geographic range [1], as a result of increased transportation and international trade, biological invasions are becoming more widespread, with potentially severe consequences for ecosystem services [2]. Invasion of banana skipper Erionota spp. have been documented in various banana-growing plots in Kerala [3]. The banana is one of the most important fruit crops in the world, and it is widely grown in tropical countries [4]. It is a favorite fruit of all classes of people and has good export potential due to its year-round availability, affordability, varietal variety, taste, nutritive and medicinal value. The banana leaves are a regular income sources of many people in South India [5]. A survey conducted in southern districts of Kerala exposed the presence of the banana leaf roller Erionota in almost all important banana varieties. The infestation percentage was up to 40 and severe defoliation with mean leaves damaged per plant to 2.88. \% [6]. Both Erionotathrax and Erionota torus were reported in different parts of Kerala [7]. E.thrax and E.torus have similar morphology often making their distinction by classical identification using morphological criteria difficult. Since there is no reliable way to separate the early stages of E. thrax, E. torus and E. acroleuca morphologically, a careful study and documentation of reared material, 
supported by reared vouchers and barcoding of individuals, is needed [8]. DNA barcode based identification has been proposed as a molecular method for assigning individual specimens to known species.DNA barcode involves DNA sequence analysis of a portion of the mitochondrial gene cytochrome c oxidase subunit I (COI) of about 600-700 bp. The basic concept is that barcode variation between even closely related species will be substantially greater than the variations observed within species[9].Many invasive species' early life stages have been successfully identified using DNA barcoding.Armstrong and Ball discovered that the COI barcode marker outperformed earlier molecular assays when it came to identifying moth species from eggs found on imported vehicles.In addition, compared to earlier methods, this barcoding marker was able to identify a wider taxonomic range of foreign species [10] In a study of blue butterflies from the Lycaenidae family, Wiemers et al., discovered that interspecific variance outnumbers intraspecific variation and that there is no barcode gap.[11] Footti et al., used DNA barcoding to distinguish over 300 species of aphids (Hemiptera: Aphidae) and found that 96 percent of them were highly distinguished, despite limited sequence variation. The aphids complicated life cycles and parthenogenic manner of reproduction proved to be no impediment[12].The barcoding of the maize weevil, Sitophilus zeamais (Motsch.) and rice weevil, Sitophilus oryzae (L.) mitochondrial cytochrome oxidase I gene and subsequent alignment by Thomas et al., revealed that out of 620 base pairs in the sequences, 82 were found to be different between the two species, despite their morphological similarities.The precise identification of various insect pests would undoubtedly aid in the development of effective management techniques, such as natural enemy selection and IPM. Because conventional taxonomy has limitations in identifying a pest, the researchers turned to DNA barcoding for identification [13]. PushaprajKarthika et al., used DNA barcoding to track the evolutionary ancestry of 15 insect pests that attack horticultural crops in South India. They were able to screen the pests and determine their genetic variations, resulting in better IPM control [14]. The objective of this study is to assess the applicability of DNA barcoding to identify the invasiveness of Erionotaspp. which cause serious damage to banana in Malabar region of Kerala, India.

\section{Materials and methods}

\subsection{DNA barcoding of Erionota torus}

\subsubsection{Collection of specimens}

The larvae of butterflies of Erionotaspp were collected from severely infested banana plantations at Payyanur located latitude $12.0972^{\circ} \mathrm{N}$, longitude $75.1934^{\circ} \mathrm{E}$ and altitude of 19 MSL in Kannur district of Kerala. The adults that emerged from the collected larvae were then preserved in the laboratory at $-200 \mathrm{C}$ for genomic DNA extraction. All the details of samples like sample ID, date of collection, location of collection were recorded. Due care was taken to prevent any damage to the wings and other taxonomic features.

\subsubsection{DNA preparation of Erionota torus (Evans)}

The genomic DNA of Erionota torus was isolated from one of its leg muscles, using Macherey-Nagel NucleospinTissue kit (Machery-Nagel, Duren, Germany) as per the Manufacturer's protocol.

\subsubsection{PCR amplification of the COI region}

The PCR amplification was performed in a thermal cycler,Sure Cycler 8800 (Agilent Technologies) following the standard protocols.The PCR reaction mixture consisted of 2 nanograms of genomic DNA in $1 \mu \mathrm{l}, 1 \mu \mathrm{l}$ each forward and reverse primers at a concentration of $10 \mu \mathrm{M}, 2.5 \mu \mathrm{l}$ of dNTPs $(2 \mathrm{mM}), 2.5 \mu \mathrm{l} 10 \mathrm{X}$ reaction buffer, $0.20 \mu \mathrm{lTaq}$ polymerase $(5 \mathrm{U} / \mu \mathrm{l})$ and $16.8 \mu \mathrm{H} 2 \mathrm{O}$. The thermo cycling program consist of $95^{\circ} \mathrm{C} / 3$ minutes for initial denaturation followed by 45 cycles of $95{ }^{\circ} \mathrm{C} / 10$ seconds for denaturation, annealing temperature of $50{ }^{\circ} \mathrm{C} / 45$ seconds, the elongation at $72{ }^{\circ} \mathrm{C} / 45$ seconds and with a final extension 
of $72{ }^{\circ} \mathrm{C}$ for 3 minutes. The PCR amplified product was column purified using Mo Bio Ultra Clean PCR Clean-up Kit (Mo Bio Laboratories, Inc. California) as per the Manufacturer's instructions.

\subsubsection{DNA sequencing and analysis}

The amplified and purified product was then sequenced with forward and reverse primers using the Sanger's sequencing method at Sci Genome Labs, Cochin. The forward and reverse sequences were aligned and the consensus sequence was used for further analysis. The phylogeny analysis was done using the NCBI nucleotide BLAST software [15]

\subsection{Invasiveness study}

Infestation on cultivars was observed in the chosen area using the roving survey approach. Ten plants were chosen at random from each plot. A plant was considered infested if it had at least one leaf roll in each leaf. Different stages of the banana were categorized as per Okolle et al. with appropriate modification as bunched plants (BP), flowering plants (FP) and pre flowered plants (PF). Plants with new bunches were classified as $\mathrm{BP}$ until the bunches were harvested, and plants with newly developed flowers were classified as FP until the female phase was completed [16]. Plants without flowers that were 4-6 months old were designated as PF. The percentage of plants infested was estimated using a hundred randomly selected plants from each plot.

\section{Results and discussion}

Phylogeny analysis of Erionota torus was carried out by the partial sequencing of the mitochondrial COI which yielded a 630 bp product by PCR amplification. GenBank deposition of the above product indicated the novel and first time records of Erionota torus from Malabar region of Kerala and was provided with a genbank accession number KT783538.1 .It was followed by the phylogenetic tree construction by Fast Minimum Evolution method (Fig.1) and by neighbor joining method (Fig.2) [17]. Genbank analysis showed the sequence has $100 \%$ identity with E. torus (GenBank accession number: KP299167.1), 98.10\% identity with GenBank accession number:KY019746.1 which is deposited as Erionotathrax and $95.73 \%$ identity with GenBank accession number: KY019745.1 which is deposited as Erionota spp. by Sahoo et al. [18], and are its nearest neighbors. The phylogenetic tree constructed by Neighbor joining method using the partial nucleotide sequence of COI gene also indicated that both the species Erionotathrax and Erionota torus are monophyletic [17] The phylogenetic tree of Erionota torus constructed by fast minimum evolution and neighbour joining method using the partial nucleotide sequence of COI gene (Fig 1\&2) clearly indicatesnthe phylogenetic relationships of Erionota torus and E.thrax reported and showed a very close similarity which can even be considered as subspecies (Gen bank accession numbers KY019746 for E.thrax and KT783538 for E.torus ,however the Erionota species reported by Sahoo etal differ from E.torus reported from our laboratory with $95.73 \%$ identity.The identification of these species based on their larval morphology is rather difficult because of their extreme morphological similarity. More over E. thrax and E. torus are common pests of banana feeding on the leaves. Thus classical taxonomic method using morphological features of the early stages of two species is difficult. Because there is no published information on whether one or both species of Erionotae coexist during the periodic outbreaks of banana skipper in Malabar region, accurate species-level knowledge would be immensely important for implementing successful management programmes against this invasive pest.Heavy infestation of banana leaf roller, Erionota torus Evans, was observed in the banana cultivating areas of Malabar region of Kerala . Adult butterflies lay small creamy yellow eggs on the under surface of banana leaves. After hatching the different larval instars damage leaves by rolling and feeding (Fig.3). They feed on almost all cultivars of banana plantain and 
cause severe damage. This large scale damage lowers banana yields by delayed fruit maturity, reduced bunch size and preventing the traditional use of leaves The infestation percentage was more during monsoon and post monsoon seasons, ranging from 10 to $40 \%$ and up to $50 \%$ loss of plant leaf area (Fig.4)[19].

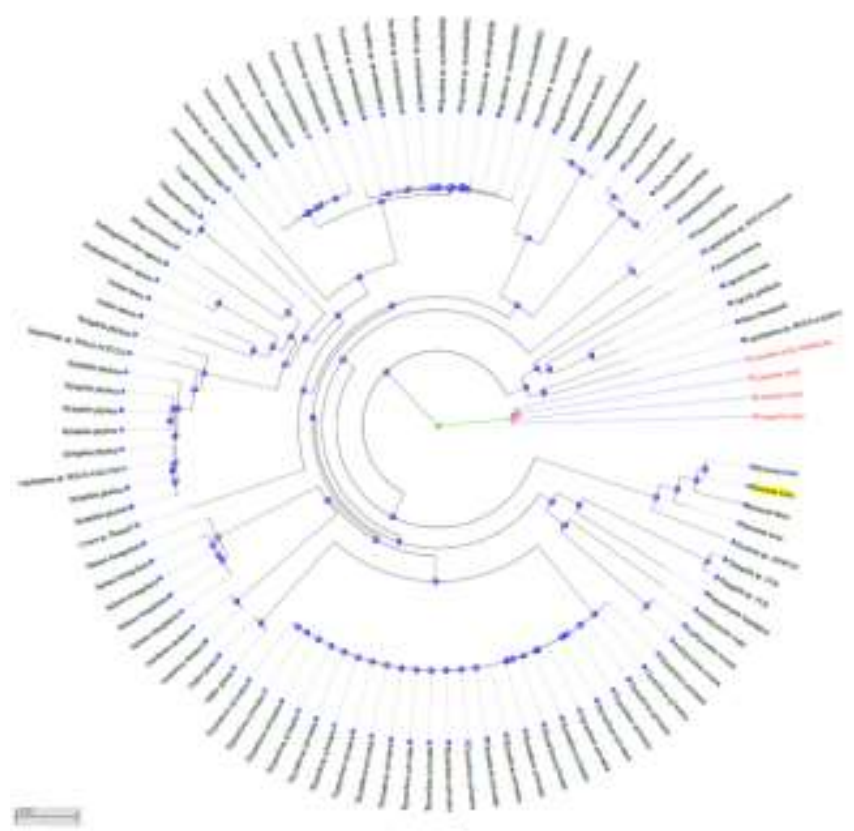

Figure 1. The phylogenetic tree of Erionota torus constructed by fast minimum evolution method using the partial nucleotide sequence of COI gene.

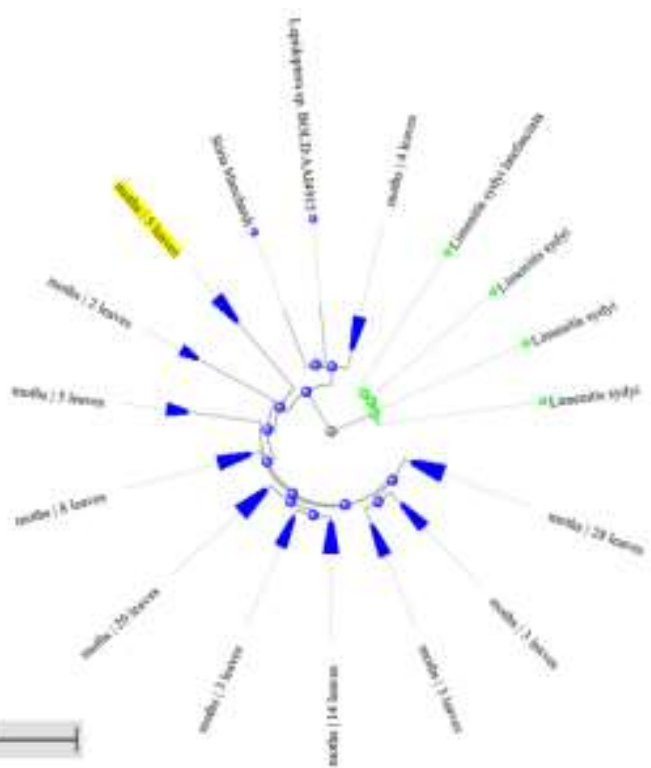

Figure 2. The phylogenetic tree of $E$ torus constructed by neighbourjoioning method using the partial nucleotide sequence of COI gene. 


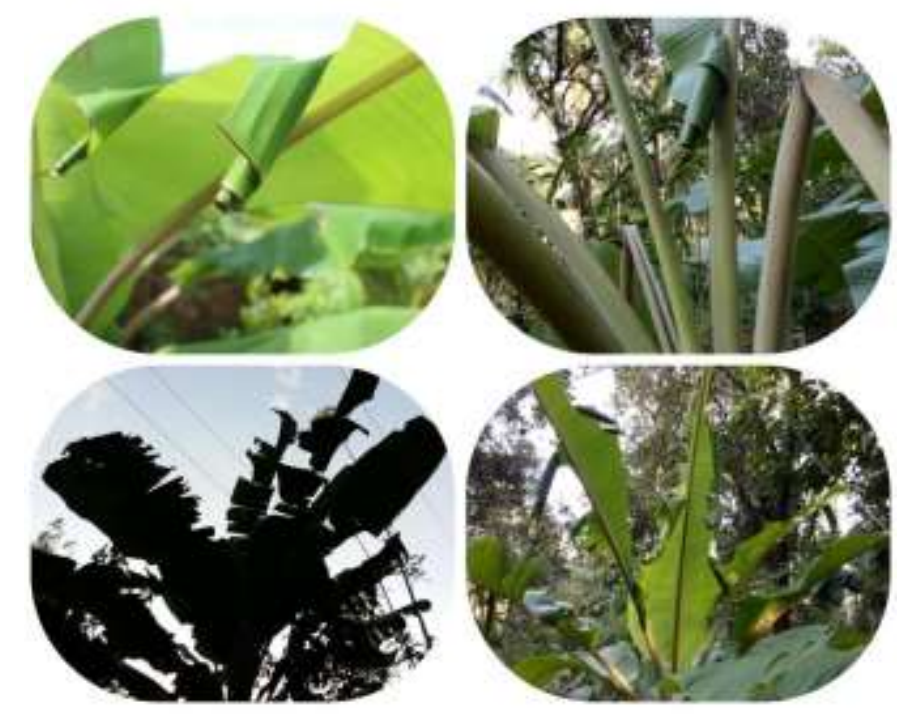

Figure 3. Infested banana leaf and fully infested plants.

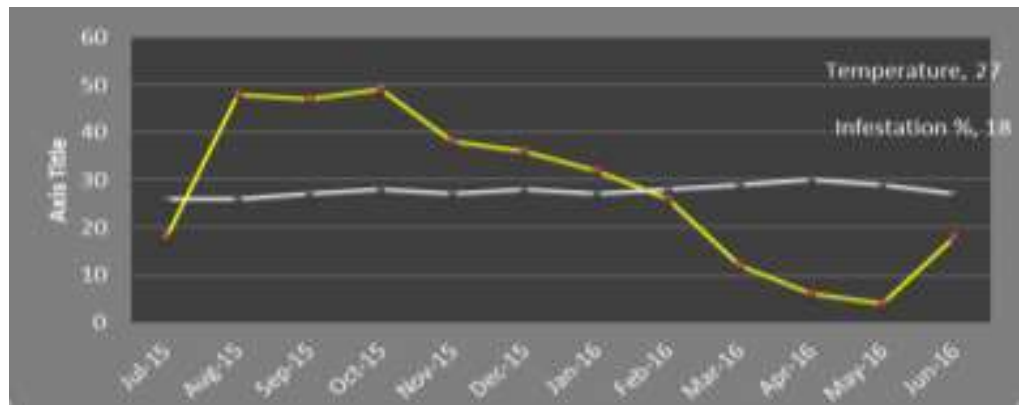

Figure 4. Incidence of E. torus (2015-16) in banana plantation at Payyanur.

\section{Conclusion}

Invasion of banana leaf roller Erionota spp. has been found throughout Kerala especially in banana plantations in Malabar region .Many studies reported that the banana leaf rollers E. thrax and E. torus coexist in Kerala, and that they should be considered as a single species.In order to develop successful biological control programmes to manage this pest, species level identification is required.DNA barcodes are used in invasive species programmes because they allow for early and rapid detection of new invading species.Invasive species can be recognised at any stage of their life cycles thanks to rapid genetic identification that does not require any morphologically mature features, whether vegetative or reproductive. Surveying specimens at mature, reproductive, or advanced life stages, which are typically only available at certain times of year or under specified climatic conditions, is typically required for morphological identification of species [20]. Because the early stages of $E$. thrax and E. torus are difficult to differentiate, and because they are frequent banana pests, morphological identification of species is challenging.The COI sequences of banana skipper confirm the presence of E.torus species in infested areas, and all parasitoid species collected during the course of the investigation were E.torus. DNA barcoding techniques to identify a species will be an easiest way in quick identification and to implement management strategies and prevent the further spread of invasive species.

Author Contributions: Conceptualization, Abdul Jaleel K.; methodology, Abdul jaleel K and Ghosh SM; software, Abduljaleel K.; validation, AbdulJaleel K and Ghosh SM.; investigation, Abdul Jaleel 
K.; data curation, Abdul Jaleel K.; writing - original draft preparation, Abdul Jaleel K; writingreview and editing, Ghosh S M.; visualization, Abdul Jaleel K.; supervision, Ghosh SM. All authors have read and agreed to the published version of the manuscript.

Funding: This research received no external funding

Informed Consent Statement: Not applicable

Data Availability Statement: The study did not report any data.

Acknowledgments: The authors acknowledge the Research Department of Zoology, Government College, Kasaragod for the technical support. The authors also wish to thank Dr. Mini P V and Dr Thomas George for their encouragement to do this study.

Conflicts of Interest: The authors declare no conflict of interest.

\section{References}

1. Richardson ,D.M ; Pysek , P; Rejmanek, M; Barbour ,M.G ; Panetta, F.D; West,C.J.Naturalization and invasion of alien plants: Concepts and definitions. Diversity and Distributions. 2000b. 6: 93-107. doi: 10.1046/j.1472-4642.2000.00083.x Author

2. $\quad$ Mack ,R.N., Simberloff ,D., Londsale ,W.M., Evans, H., Clout, M., Bazzaz ,F.A . Biotic invasions: Causes, epidemiology, global consequences, and control. Ecological Applications.2000.10:689-710. doi:10.1890/10510761(2000)010[0689:BICEGC2.0.CO;2

3. Nandakumar ,T.Banana farmers reel under 'butterfly' attack. The Hindu. July 07. 2014.

4. Kumar, K.P.S. , Bhowmik, Debjit ., Duraivel .S., Manivannan, Umadevi. Traditional and medicinal uses of banana. Journal of Pharmacognosy and Phytochemistry. 2012. 1. 51-63.

5. Nayar,N.M.The bananas:botany,origin, dispersal.HorticulturalReviews.2010.117-164 https://doi.org/10.1002/9780470527238.ch2

6. Sivakumar ,T., Jiji ,T., Anitha, N. Field observations on banana skipper Erionotathrax L. (Hesperiidae: Lepidoptera) and its avian predators from southern peninsular India. Current Biotica. 2014.3 (8): 220-227.

7. Raju ,D., K. Kunte, Kalesh, S, Chandrashekaran, V. K., Manoj, P., Ogale ,H., Sanap ,R. 2020. Erionota torus Evans, 1941rounded palm-red eye. Kunte K, S Sondhi, P. Roy (eds.). Butterflies of India, v. 2.74. Indian Foundation for Butterflies. http:// www.ifoundbutter flies.org/sp/2756/Erionota torus.

8. Cock ,M .J. A critical review of the literature on the pest Erionotaspp. (Lepidoptera, Hesperiidae): taxonomy, distribution, food plants, early stages, natural enemies and biological control. CAB Reviews. 2015. 10 (7): 1-30.

9. P.D.N. Hebert, A.Cywinska A, S.L.Ball , J.R.deWaard . Biological identifications through DNA barcodes. Proceedings of the Royal Society of London B-Biological Sciences.2003. Vol.270 (1512) pp313-321,2003.

10. Armstrong KF, Ball SL DNA barcodes for biosecurity: invasivespecies identification. Philosophical Transactions of the Royal Society B:Biological Sciences.2005.360, 1813-1823.

11. Wiemers M, Fiedler K. (2007) Does the DNA barcoding gap exist? - a case study in blue butterflies (Lepidoptera: Lycaenidae). Frontiers in Zoology 4:8. https://doi.org/10.1186/1742- 9994-4-8

12. Foottit RG, Maw HE, VON Dohlen CD, Hebert PD. Species identification of aphids (Insecta: Hemiptera: Aphididae) through DNA barcodes. Mol EcolResour. 2008. Nov;8(6):1189-201. doi: 10.1111/j.1755-0998.2008.02297.x. PMID: 21586006.

13. Thomas, A., Devi, S. R. and Gaur, A.. DNA barcoding of immature stages of Sitophilus oryzae and Sitophilus zeamais (Coleoptera: Curculionidae) using mitochondrial cytochrome oxidase I. Indian Journal of Entomology. 2015.77(1): 66-70.

14. Pushparaj, Karthika., Natraj, Krishnaveni., Chithravel, Vadivalagan., Kadarkarai, Murugan., Marcello, Nicoletti. And Giovanni, Benelli. . $\quad$ DNA barcoding and evolutionary lineage of15 insect pests of horticultural crops in South India. Karbala International Journal of Modern science. 2016. 2(3): 156-168.

15. http://www.blast.ncbi.nlm.nih.gov/Blast.cgi.

16. Justin, Okolle\&Mansor, Mashhor\& Hassan, Ahmad. Spatial distribution of banana skipper (ErionotathraxL.) (Lepidoptera: Hesperiidae) and its parasitoids in a Cavendish banana plantation, Penang, Malaysia. Insect Science. $\quad 2006.13 . \quad 381 \quad-\quad 389$. 10.1111/j.1744-7917.2006.00107.x.

17. Abdul Jaleel K.,Ghosh.S.M and Jiji Joseph V. DNA Barcoding and Evolutionary lineage of banana skipper Erionota torus (Evans)(Lepidoptera:Hesperiidae) from Malabar, a part of Southern Western Ghats ,India .Int.Jou.of Scientific research in Biological sciences.2019.6 (4) pp 29-32.

18. Sahoo,R.K., Warren,A.D., Wahlberg,N., Brower,A.V., Lukhtanov,V.A., Kodandaramaiah,U.Ten genes and two topologies : an exploration of higher relationships in skipper butterflies (Hesperiidae) . 2016.Peer J. 4, E2653 .

19. Abdul Jaleel K.,S M Ghosh Biology and damage of Banana skipper Erionota torus (Evans)from Malabar region of Kerala.IndianJou.Entomology. 2020.82 (3) pp 429-434 .

20. Cross, Hugh \& Lowe, Andrew \&Gurgel, Carlos. DNA Barcoding of Invasive Species.2010. 10.1002/9781444329988.ch22. 